\title{
Autobiography, autofiction, representation, interrogation, remembering and forgetting
}

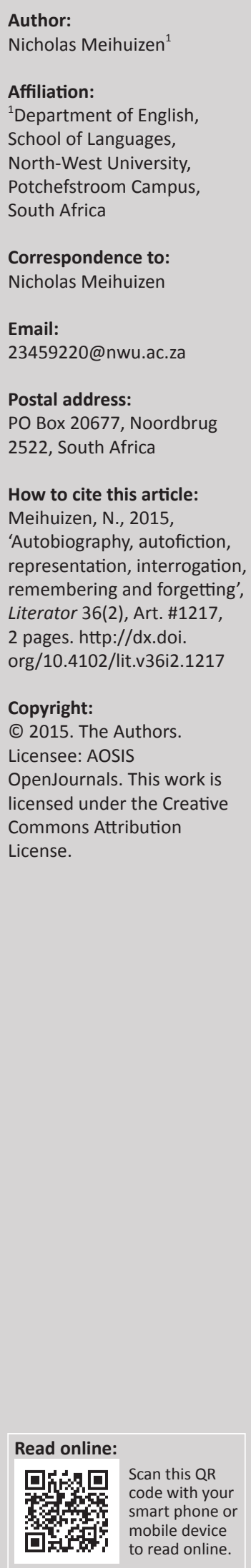

This special edition of Literator, devoted to autobiography, is based on papers delivered at the Workshop on Autobiography, Autofiction and Life Writing, held at North-West University, Potchefstroom campus, between the 07 and 09 August 2014. The bilingual workshop (French and English) was hosted by the Department of French and was seamlessly coordinated and run by Professor Elisabeth Snyman and her team. Selected French papers from the workshop will be published separately, in French Studies in Southern Africa. Scholars attended from different parts of the country and from much further afield. We were privileged to have two worldrenowned keynote speakers. Professor Michael Sheringham from All Souls College, Oxford, gave a fascinating address included in this special edition; it is presented (at his request) largely in its original oral format. The other keynote speaker, Dr Catherine Viollet, from the CNRS (Centre national de la recherche scientifique) in France, spoke on genetic criticism and autobiography. Sadly, she passed away a bare month after the workshop, on 15 September 2014. We take this opportunity to extend our condolences to her family and friends. (Her talk was not available for publication, but readers interested in her work are recommended to look at her essay, 'Proust's "Confession of a Young Girl": Truth or Fiction?', in Genetic Criticism: Texts and Avant-textes, edited by Jed Deppman, Daniel Ferrer and Michael Groden, published in 2004 by the University of Pennsylvania Press.)

Michael Sheringham's address, 'Autobiographical turning points', draws on Baudelaire, St Augustine, Henry James, Virginia Woolf, Malcolm $X$ and Samuel Beckett to show how remembering and forgetting are inseparable in the autobiographical process. He looks at the designs, the patterns, that autobiographers make of their memories and asks how memory might, in turn, have 'designs' on them. The question takes into consideration the structuring implications of turning points in the account of a life and the roles of the converse forces of forgetting and subjective destabilisation. There are two ways of looking at turning points: either as metaphors, used as a means of thinking about complex processes, or as causative agents. As causative agents, they would incorporate narrative, order and coherence, thus following the Augustinian route generally taken by autobiographers over the centuries. Sheringham shows how Henry James offers a delightfully circumspect response to this view, which underlines the first notion - that the turning point is a device, a means of paying attention to the self on the basis of a transaction between the self and past experience. Its semi-fictive nature is understood. Memory, far from being a 'pristine storehouse of the past', works by 'engendering oblivion'; attending to certain events connotes, as Freud has it, forgetting others. Knowing a memory in precise terms would fix it for all time, a somewhat delusory subjective idealisation, as the imposed continuity of life stories actually conceals much of the past. Virginia Woolf, in To the Lighthouse for example, does not create aesthetic order to explain her relationship with her mother, but 'sifts, reconstructs, locates borders between public and private, what is remembered and forgotten, what is fact and what is fiction'. Here the turning point is 'provisional, semi-fictional, forensic, a cognitive instrument, part of an ongoing narrative' 'actively transformed by the present process of recollection'. With this understanding, the past is not so much represented, as interrogated. It is thus, so to speak, ever present, can never simply be consigned to the past.

Joanne Leonard's Being in pictures: An intimate photo memoir is carefully examined by Heilna du Plooy. Du Plooy shows how Leonard's photo collages express personal emotions and reactions to public events, revealing her development over the years through a type of 'narrative' that combines text and image. That is, these photo collages are constructed representations that convey the relation between identity and narrative, and which show not only how memory is understood, but how it works. Du Plooy's undertaking is usefully supported by certain critical and theoretical approaches, such as those of David Herman, Mieke Bal, Tobias Döring and, especially, Paul Ricoeur, to engage with, in fact, the turning points embedded in Leonard's photos and collages. Although these particular turning points indeed provide a measure of autobiographical coherence, this is offset by elements from fiction and fantasy that Leonard incorporates, to do with (say) emotional states, and which prompt multiple interpretations. Thus, 
narrative coherence is simultaneously created and suspended by the many layers of representation, which provide their own means of interrogating in an ongoing way what might otherwise be considered fixed and final. Du Plooy refers to Leonard's 'hermeneutical view of her life and work as an extended search for and development of identity', based on unique personal reactions to key experiences. These unique reactions are premised on a belief in autobiography's ability to uncover an authentic inner core in the face of possible subjectivist idealism.

Philip van der Merwe and Ian Bekker present E.L. Doctorow's World's Fair as autofiction that takes its cue from the author's childhood. Van der Merwe and Bekker see the work as being constructed in alternating phases, negative and positive, comic and serious, light-hearted and tragic. They term this alternation (following Bakhtin) a 'carnivalesque dialectic', which takes things apart, so to speak, in order to put them back together. Thus, personal growth is accomplished through dialectic. Their emphasis is on the literary, constructed value of this work, which nevertheless also contains actual personal references, along with historical, factual references to New York. The approach in the novel is, in a sense, an anti-turning point one, in that the drama conveyed by Doctorow never 'comes to crisis'. The emphasis on 'carnival' and 'carnivalesque dialectic' helps convey this fact.

In considering certain landscape and seascape poems by Richard Murphy, Elsa Meihuizen emphasises the'relationship between the creative self and a particular place', which results in a 'double portrait'. 'Place' is inclusive, a locus of the material environment with its interrelated parts, including the element of human participation. Meihuizen tells of how Murphy's chosen environment is Connemara, in north-west Ireland, with its overtones of the poet's cherished childhood. Place and life are deeply intricated in each other, a notion apparent in Peter Perretan's idea of 'eco-autobiography', the basis of the 'double portrait', where the personal is reflected in the environment. But there is never an exact correlation between self and environment; the writer must accept that the element of otherness in the environment (that 'something in the environment' in Joseph Swann's terms) can never be fully assumed and so offers a relationship that is continually openended, always responsive to renewal and reinterpretation.

Catherine du Toit's paper is on Henri Pierre Roché (author of the autofictional novel Jules et Jim) and Helen Hessel, his lover and wife of his friend Franz Hessel (the 'Jules' of the book). Roché wrote a diary, which emphasised how his life was devoted to 'the creation of a body of work which would examine moral, intellectual, social and sexual relations between women and men'; the diary is at its most intense when dealing with his relationship with Helen, whom he encouraged to write about their passionate affair from her point of view, in horizontal 'counterpoint' to and in vertical 'harmony' with his. Du Toit shows how 'a juxtaposed reading of the two diaries generates a fascinatingly dense texture' that incorporates intertextual references to, for instance, Don Juan and Otto Weininger (author of the philosophical work Sex and Character), role reversal, as well as, again, carnivalesque aspects, all of which help to uncover the 'mechanisms of seduction at play'.

Here, then, is a varied selection of pieces, showing various approaches to autobiography. It is only to be expected, in this day and age, that none of these contributions subscribes to the Augustinian notion of autobiography discussed by Sheringham in his address - that the life is a coherent whole reconstructed through the workings of unadulterated memory. Autofiction, subjective destabilisation, provisionality and multivalency are givens. These features must continue to assert a fascination over anyone who comes into contact with them, because they demand a fluid responsiveness that is interactive in nature. Thus, the present contributions help to underline the fact that authentic subjective information, stored and recorded in many ways, can also be felt, appreciated and understood in many ways. Which is not to say that 'anything goes' when it comes to memorial reconstruction of a life. Authenticity lies in the tangible power of expression rendered by the writer, itself a negotiated coming to terms with the forces of existence (including remembering and forgetting) that results in an aesthetic construction; it is this, when successful, that offers up to us the presence of a particular subjective centre of living energies that somehow helps affirm our own. 